\title{
НЕПЕРЕРВНА ПЕДАГОГІЧНА ОСВІТА XXI СТОЛІТТЯ: ДОСВІД, ІННОВАЦІї, ТЕНДЕНЦІї
}

\author{
ХІХ Міжнародні мистецько-педагогічні читання пам'яті професора \\ Оксани Петрівни Руднищької
}

https://doi.org/10.37472/2707-305X-2021-3-2-3-7

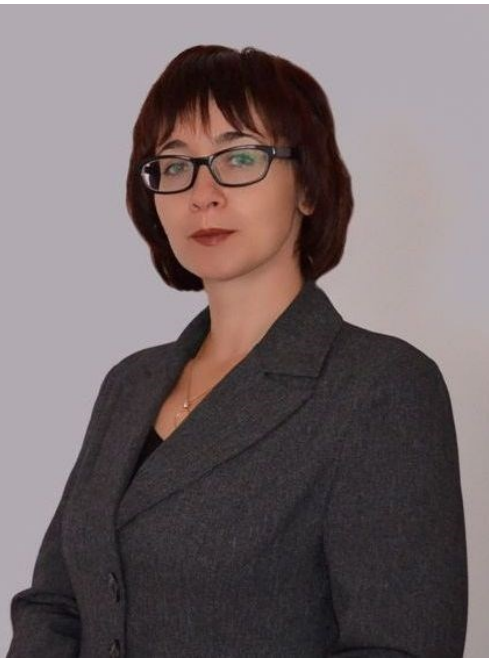

BOBK

\section{Мирослава Петрівна}

доктор педагогічних наук, старший науковий

співробітник, завідувач відділу змісту і технологій педагогічної освіти Iнституту педагогічної освіти і освіти дорослих імені Івана Зязюна НАПН України, м. Київ, Україна

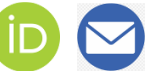

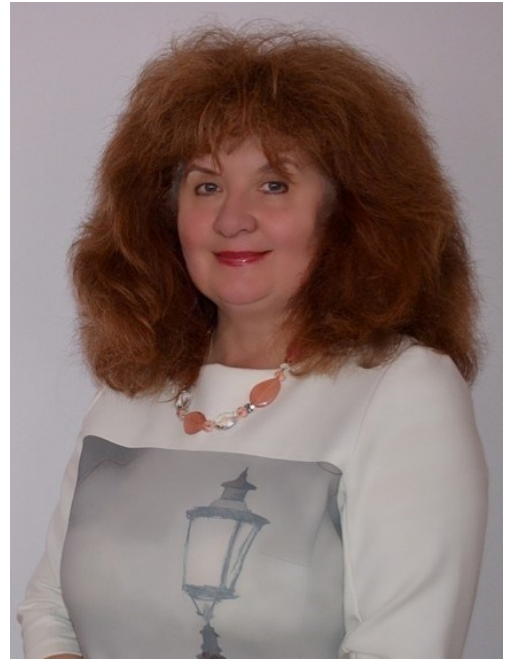

ФІЛІПЧУК

Наталія Олександрівна доктор педагогічних наук, старший науковий співробітник, провідний науковий співробітник відділу змісту і технологій педагогічної освіти Iнституту педагогічної освіти і освіти дорослих імені Івана Зязюна НАПН України, м. Київ, Україна

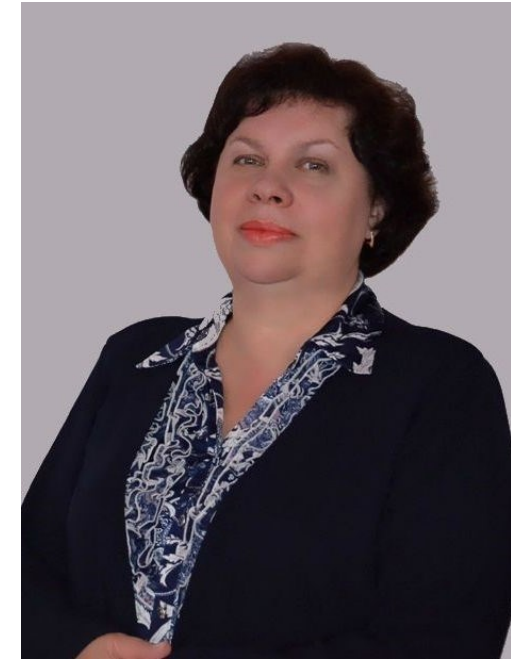

СОЛОМАХА

Світлана Олександрівна кандидат педагогічних наук, старший науковий співробітник відділу змісту і технологій педагогічної освіти IHсmumymy педагогічної освіти і освіти дорослих імені Івана Зязюна НАПН України, м. Київ, Україна

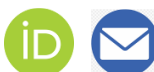

Анотація. У повідомленні висвітлено проблематику проведення ХІХ Міжнародних педагогічно-мистецьких читань пам'яті професора О.П. Рудницької «Неперервна педагогічна освіта в Україні і зарубіжжі: досвід, інновації, тенденції» (1 грудня 2021 р., м. Київ), організація яких спрямована на утвердження партнерської взаємодії закладів освіти і наукових інституцій у здійсненні реформування мистецької і педагогічної освіти, вшанування пам'яті знакових для української освіти постатей, величних у продукуванні інноваційних науководослідницьких ідей особистостей. Акцентовано увагу на науковій спадщині Оксани Петрівни Рудницької (19462002 рр.), доктора педагогічних наук, професора, яка стала одним із фундаторів мистецької освіти в Україні, обгрунтувала методологічні, теоретичні основи мистецької педагогіки. Представлено досягнення відділу змісту і технологій педагогічної освіти Інституту педагогічної освіти і освіти дорослих імені Івана Зязюна НАПН України у збереженні наукової спадщини О.П. Рудницької; окреслено перспективи популяризації ідей дослідниці в сучасному науково-освітньому просторі.

Ключові слова: педагогічна освіта; мистецька освіта; Оксана Петрівна Рудницька; мистецько-педагогічні читання; наукова спадина; Інститут педагогічної освіти і освіти дорослих імені Івана Зязюна НАПН України. 
При майстрах якось легше. Вони - як Атланти, держать небо на плечах. Тому і $є$ висота.

Ліна Костенко

В сучасному українському науково-освітньому просторі наявна унікальна традиція, спрямована на утвердження відкритого професійного діалогу між науковцями й освітянами з різних регіонів України, зарубіжних країн з проблем теорії і практики мистецької, педагогічної освіти, проведення щорічних міжнародних мистецькопедагогічних читань пам'яті професора Оксани Петрівни Рудницької. Місією заходу є партнерська взаємодія закладів освіти і наукових інституцій у здійсненні реформування мистецької і педагогічної освіти, вшанування пам'яті знакових для української освіти постатей, величних у продукуванні інноваційних науково-дослідницьких ідей особистостей. 3-поміж наших сучасників, яких вирізняє культура наукового наставництва, відданість науково-дослідницькій діяльності, відповідальність за інноваційні зміни у сфері освіти, постать Оксани Петрівни Рудницької (19462002 рр.), доктора педагогічних наук, професора, яка стала одним із фундаторів мистецької освіти в Україні, обгрунтувала методологічні, теоретичні основи мистецької педагогіки, виявила методичні засади викладання дисциплін художньо-естетичного спрямування, окреслила пріоритетні напрями подальшого вдосконалення мистецької освіти, розкрила її взаємозв'язок з основами загальної педагогіки.

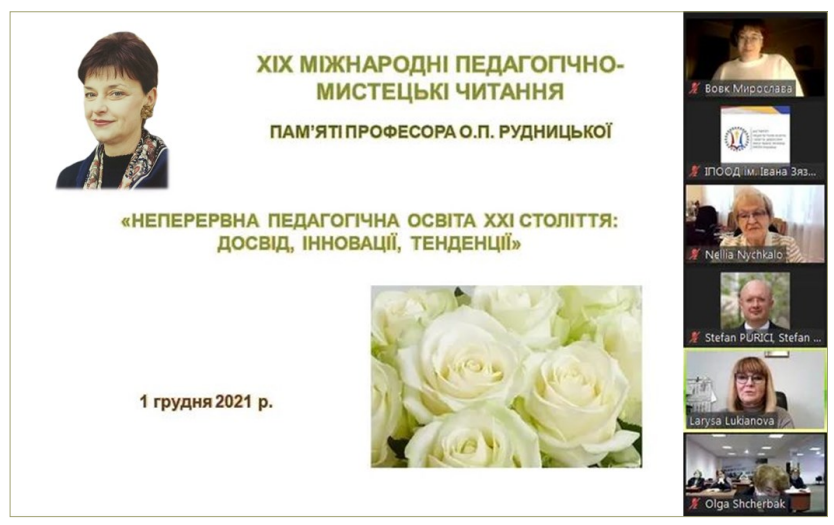

О.П. Рудницька народилася 1 грудня 1946 р. в Києві в сім'ї службовців. У 1965 р. закінчила Київську середню спеціалізовану музичну школуінтернат імені М.В. Лисенка (нині - Київський державний музичний ліцей імені М.В. Лисенка). Навчалась на фортепіанному відділенні у Київській державній консерваторії імені П.І. Чайковського (1965-1970рр.). По закінченні консерваторії працювала на кафедрі гри на музичних інструмен- тах музично-педагогічного факультету Київського державного педагогічного інституту імені О.М. Горького (нині - Національний педагогіч ний університет імені М.П. Драгоманова), яку тоді очолював кандидат мистецтвознавства, відомий музикант та методист М.Т. Лисенко. Згодом кафедрою керував заслужений артист України, доцент В.М. Рязанцев. Саме на цій кафедрі Оксана Петрівна пройшла шлях професійного зростання від концертмейстера до завідувача. 31995 до 2000 рр. працювала на посадах професора і завідувача кафедри теорії, історії музики та гри на музичних інструментах Національного педагогічного університету імені М.П. Драгоманова (нині це кафедра педагогіки мистецтва та фортепіанного виконавства, яку очолює доктор педагогічних наук, професор О.П. Щолокова).

у 1977 р. О.П. Рудницька захистила кандидатську дисертацію на тему «Формування естетичних оцінок студентів педагогічних вузів (на матеріалах музики)» (науковий керівник - кандидат педагогічних наук Т.І. Цвелих) та здобула науковий ступінь кандидата педагогічних наук. У 1994 р. захистила докторську дисертацію на тему «Формування музичного сприйняття в системі розвитку педагогічної культури майбутнього вчителя» (науковий консультант - доктор педагогічних наук, професор В.І.Бондар) та здобула науковий ступінь доктора педагогічних наук за спеціальністю 13.00.01 - загальна педагогіка та історія педагогіки.

Оксана Петрівна Рудницька вперше у вітчизняній педагогічній науці:

- виокремила мистецьку освіту як самостійну галузь професійної освіти;

- обґрунтувала її методологічні, теоретичні та методичні засади;

- визначила пріоритети їі розвитку в умовах зміни освітньої парадигми та соціокультурної динаміки XXI ст.;

- окреслила вплив мистецтва на формування особистості у контексті модернізації та глобалізації культурно-освітніх процесів у світі.

3 ініціативи директора Інституту педагогіки і психології професійної освіти АПН України (нині - Інститут педагогічної освіти і освіти дорослих імені Івана Зязюна НАПН України) академіка І.А. Зязюна та його заступника з науко- 
вої роботи академіка Н.Г. Ничкало у квітні 1995 р. О.П. Рудницька очолила новостворену лабораторію мистецької освіти за сумісництвом. Напрямами наукових досліджень лабораторії стали:

- обґрунтування методологічних засад неперервної мистецької освіти;

- вивчення історичної ретроспективи мистецько-педагогічного досвіду;

- дослідження системи мистецької освіти зарубіжних країн;

- визначення закономірностей, принципів, форм і методів формування цілісного художнього сприйняття, яке є стрижневим у розвитку культури особистості;

- виявлення механізмів ціннісно-смислового осягнення змісту художнього твору у процесі спілкування з ним;

- розроблення інноваційних інтерактивних методів і технологій підготовки фахівців мистецьких спеціалізацій тощо.

Концепція наукових досліджень Оксани Петрівни Рудницької ґрунтувалася на сучасних підходах до формування духовності особистості, спираючись на думку В. Сухомлинського про те, що мистецтво - це час і простір, у якому живе краса людського духу. А тому пізнання цінностей мистецтва піднімає людину до розуміння прекрасного. В основі концепції дослідниці принципи глобальної освіти:

- виховання «світоглядної перспективи», що визначає рівноправність поглядів на оточуючу дійсність і культуру різних народів;

- пріоритет системного підходу до вивчення соціально-культурних процесів;

- формування відчуття причетності до розв'язання проблем як національного так і загальнолюдського значення.

Новий зміст дослідної роботи вимагав зорієнтованості на ідеї особистісно-творчого розвитку і навчання у концепціях К. Роджерса, А. Маслоу, Д. Зіглера, Дж. Келлі, С. Рубінштейна, Л. Виготського, О. Леонтьєва, В. Роменця, в яких процес розвитку і навчання людини розглядається як гуманна взаємодія наставника та вихованця на основі збереження індивідуальної цілісності та унікальності останнього, його спрямування на усвідомлення своєї людяності, приведення в гармонію духовного в собі до духовного у Всесвіті.

О.П. Рудницька одна з перших спрямовувала дослідницький пошук на обґрунтування філософських засад мистецької освіти з позицій гуманістичної філософії, герменевтики, діалектичної фено- менології, екзистенціалізму, синергетики, що, на іï думку, спонукає до глибокого аналізу культурологічно-смислового впливу мистецтва на особистість. Мета філософії мистецької освіти, на переконання Оксани Петрівни, полягає в усвідомленні сенсу мистецько-педагогічної діяльності на вищому рівні узагальнення теоретичного досвіду пізнання у філософських категоріях, законах, поняттях (Рудницька, 2002).

Наукові доробки Оксани Петрівни стали підґрунтям для подальшого розвитку досліджень відділу змісту і технологій педагогічної освіти, зокрема:

- технології розвитку педагогічної майстерності вчителя й викладача вищої школи з урахуванням емоційних законів впливу художнього образу на особистість;

- виявлення форм, методів і технологій художньо-естетичного розвитку світогляду особистості й творчого розвитку педагогів засобами мистецтва;

- вивчення психолого-педагогічних механізмів впливу мистецтва на трансформацію ціннісносмислової сфери педагогів;

- впровадження у технологій освіти дорослих в умовах формальної і неформальної освіти;

- обґрунтування змісту і методики проведення практики у закладах вищої педагогічної освіти, зокрема у процесі практичної підготовки майбутніх учителів мистецьких дисциплін тощо.

Професійний внесок Оксани Петрівни Рудницької у розвиток мистецької освіти в Україні $\epsilon$ надбанням не одного покоління педагогів. На основі її ідей формується нова генерація учителів, викладачів, молодих учених країни, що працюють у сфері мистецької освіти. Наукова школа професора О.П. Рудницької достатньо відома серед науковців України та за ї̈ межами (Л.О. Хомич, Л.І. Лимаренко, З.М. Сирота, Ю.В.Грищенко, В.О. Смікал, П.В. Харченко, О.І. Попик, Л.Ю. Москальова та ін.). Ї̈̈ послідовники здійснювали дослідження у галузі мистецької освіти, зокрема щодо використання музичного мистецтва у розвитку особистості та професійної майстерності майбутнього вчителя, вивчення впливу музичного сприйняття на становлення професійно значущих якостей майбутнього вчителя, щодо історичної ретроспективи розвитку мистецької освіти в Україні та їі регіонах. Основні ідеї професора О.П. Рудницької знайшли продовження у працях іï учнів, колег, послідовників. Зокрема це колективні монографії, підготовлені співробітниками Інституту педагогічної освіти і освіти дорослих 
імені Івана Зязюна НАПН України у співпраці 3 закладами освіти: «Мистецтво у розвитку особистості» (2005р.); «Сучасна професійна підготовка вчителя до викладання мистецьких дисциплін у загальноосвітній школі: проблеми, пошуки, знахідки» (2010р.); «Учитель мистецьких дисциплін у дискурсі педагогічної майстерності» (2013 р.); «Розвиток художньо-естетичного світогляду викладачів мистецьких дисциплін на основі інтегративного підходу» (2014); навчальнометодичний посібник «Творчий розвиток особистості засобами мистецтва» (2011р.) та ін.

Науковий спадок О.П. Рудницької налічує понад 200 праць, серед яких: «Основи наукових досліджень» (1996р.), «Мистецтво у контексті розвитку духовної культури особистості» (1997р.), «Теоретичні засади сучасної мистецької освіти» (2000 р.), «Світоглядна функція мистецтва» (2001 р.) та ін. Найбільш вагомою працею $\epsilon$ навчальний посібник «Педагогіка: загальна і мистецька» (2002р.). Цей навчальний посібник у 2003 р. вже після смерті авторки був відзначений Першою премією НАПН України у номінації «За кращу науково-методичну роботу для вчителів, викладачів».

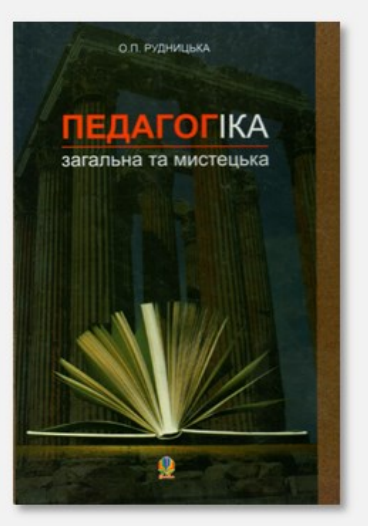

Відділ змісту і технологій педагогічної освіти Інституту педагогічної освіти і освіти дорослих імені Івана Зязюна НАПН України популяризує спадщину Оксани Петрівни Рудницької, актуалізує ї̈ ідеї у дослідницьких пошуках, у партнерській взаємодії з закладами вищої освіти, науковими установами. Зокрема створено профіль ученої у Google Scholar, оцифровано і подано в Електронну бібліотеку НАПН України навчальний посібник «Педагогіка: загальна і мистецька», видано 17 випусків збірників матеріалів за результатами проведення мистецько-педагогічних читань («Теоретичні та методичні засади неперервної мистецької освіти»; «Педагогічна майстерність як система професій-

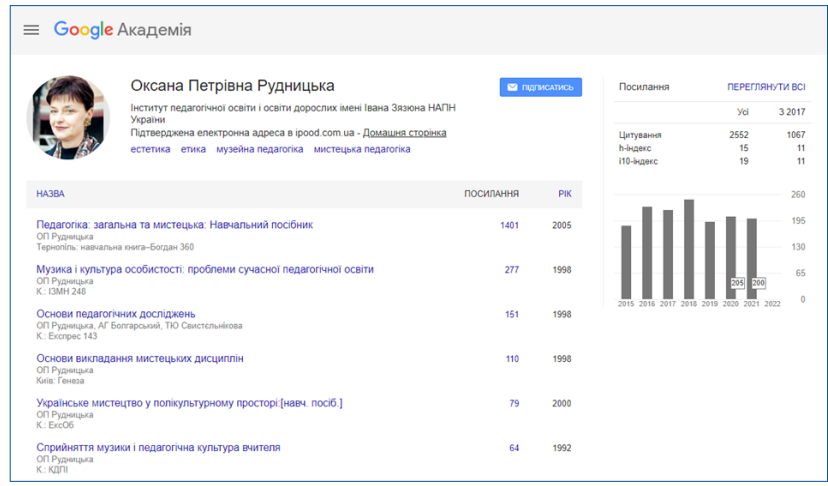

них і мистецьких компетентностей», «Неперервна педагогічна освіта XXI століття»).

Кожного року Інститут педагогічної освіти і освіти дорослих імені Івана Зязюна НАПН України, Відділення професійної освіти і освіти дорослих НАПН України спільно з партнерами проводять щорічні Міжнародні мистецько-педагогічні читання пам'яті професора Оксани Петрівни Рудницької "Неперервна педагогічна освіта ХХІ століття: досвід, інновації, тенденції». 1 грудня 2021 р. читання були проведені у співпраці з Українською асоціацією освіти дорослих, Сучавським університетом Штефана чел Маре, Кафедрою ЮНЕСКО «Неперервна професійна освіта XXI століття». У заході взяли участь близько 300 учасників дистанційно й онлайн - науковці, освітяни з різних регіонів України і зарубіжжя: Уманського державного педагогічного університет імені Павла Тичини, Національного педагогічного університету імені М.П.Драгоманова, Вінницького державного педагогічного університету імені Михайла Коцюбинського, Чернівецького національного університету імені Юрія Федьковича, Херсонського державного університету, Київського професійно-педагогічного фахового коледжу імені Антона Макаренка тощо.

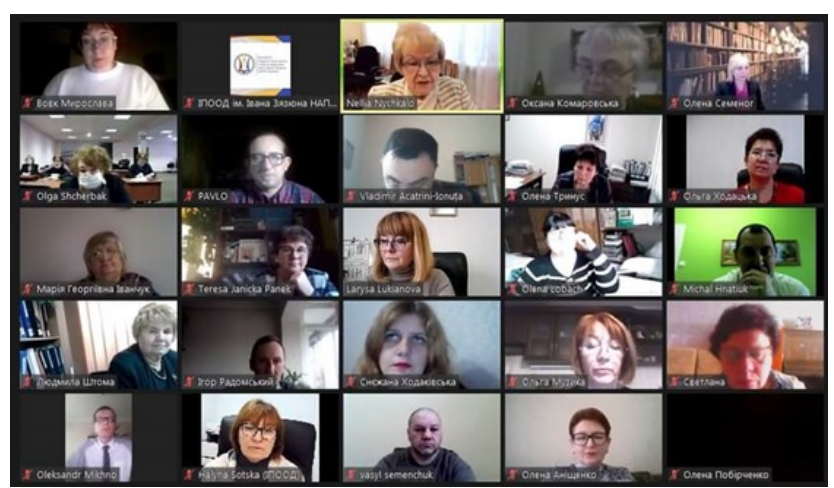

Пленарне засідання традиційно розпочав виступ камерного оркестру факультету мистецтв імені Анатолія Авдієвського Національного педагогічного університету імені М.П. Драгоманова 


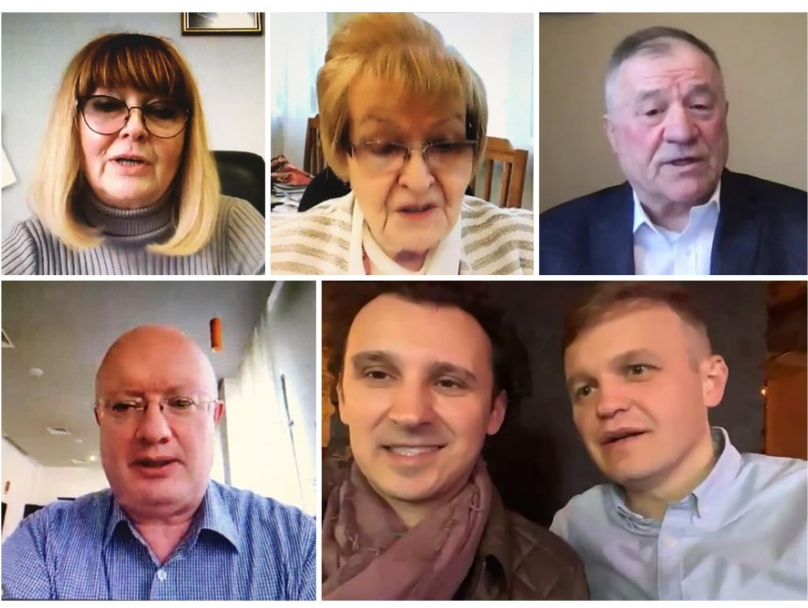

(художній керівник - заслужений діяч мистецтв України, доктор педагогічних наук, професор Василь Ілліч Федоришин; диригент - Галина Віталіїва Савченко).

3 привітальним словом звернулася до освітянської громади директор Інституту педагогічної освіти і освіти дорослих імені Івана Зязюна НАПН України, доктор педагогічних наук, професор, член-кореспондент НАПН України Лариса Борисівна Лук'янова, яка акцентувала увагу на спрямованості проведення читань як унікальної традиції, що сформувалася у науково-освітньому просторі України і покликана згуртовувати еліту України задля збагачення цінностей національної освіти, розвитку ідей непересічної особистості - засновника теорії української мистецької освіти Оксани Петрівни Рудницької. Персонологічний аспект мистецької педагогіки та сучасної філософії освіти крізь призму ідей О.П. Рудницької розкрила Нелля Григорівна Ничкало, доктор педагогічних наук, професор, дійсний член НАПН України, академік-секретар Відділення професійної освіти і освіти дорослих НАПН України.

У контексті визначення сучасних актуалітетів мистецької освіти проректор університету Штефана чел Маре (м. Сучава, Румунія), професор, почесний доктор Чернівецького національного університету імені Юрія Федьковича Штефан Пурич означив потребу подальшої конструктивної взаємодії українських і румунських науковоосвітніх осередків.

Доктор педагогічних наук, професор, дійсний член НАПН України Георгій Георгійович Філіпчук спроєктував необхідність оновлення змісту сучасної освіти з урахуванням потенціалу українознавчих наук, використання наявної культурної спадщини України, спродукованої відомими українськими науковцями, педагогами, митцями, з-поміж яких - видатний український співак
Назарій Яремчук, якому 30 листопада 2021 р. мало виповнитися 70 років.

Знаково, що до читань долучилися його сини, народні артисти України, засновники пісенного фестивалю «Родина» Дмитро Назарійович Яремчук і Назарій Назарійович Яремчук , які порушили актуальну проблему виховання особи стості на основі національних цінностей, відзначили, що для України важливо не втратити покоління, через культуру, пісню, освіту, родину формувати внутрішній світ дітей, юнацтва, особливо через пісенність, яка $€$ важливим чинником формування громадянина, особистості.

Сини Назарія Яремчука щороку організовують фестиваль «Родина», цьогоріч цей унікальний традиційних захід відбувся у напередодні ювілею Н. Яремчука у Міжнародному центрі культури мистецтв Федерації профспілок.

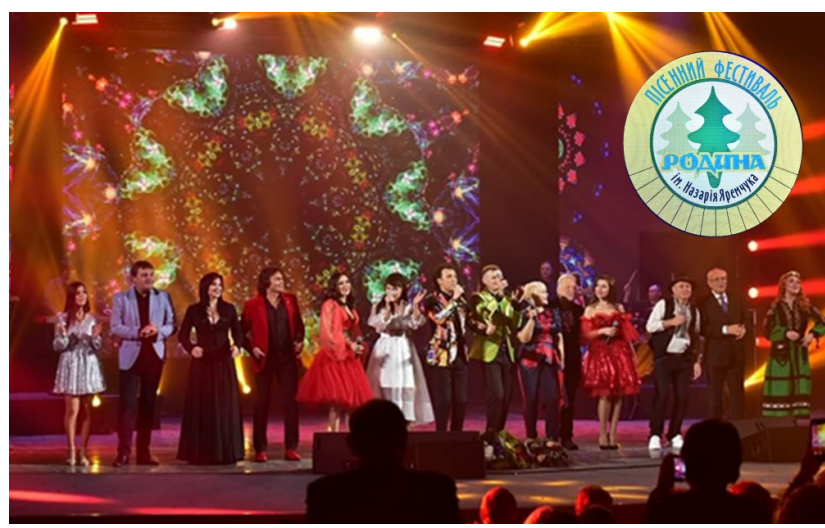

Доктор педагогічних наук, професор, декан факультету мистецтв імені Анатолія Авдієвського Національного педагогічного університету імені М.П.Драгоманова, заслужений діяч мистецтв України Василь Ілліч Федоришин акцентував увагу на специфіці формування творчої особистості, на потенціалі мистецтва, через яке можна пізнати красу й істину життя, адже навіть колискова варто трактувати як джерело світосприйняття людини, благословіння-молитву через емоційну складову дитини. Саме тому, вважає дослідник-митець, $€$ потреба актуалізації ідеї дитиноцентризму доктора філософських наук, професора, академіка НАН і НАПН України, президента НАПН України В.Г. Кременя, а також ідеї добротворчості доктора філософських наук, професора І.А. Зязюна.

Доктор педагогічних наук, професор, завідувач лабораторії естетичного виховання та мистецької освіти Інституту проблем виховання НАПН України Оксана Анатоліївна Комаровська розкрила проблему художнього пізнання та його організацію в процесі навчання мистецтва в закладі 
загальної середньої освіти, представила колективний підручник (О. Комаровська, Н. Миропольська, С. Ничкало, І. Руденко) до курсу «Мистецтво» (10 (11) клас), зміст якого свідчить про реалізацію ідеї мистецької подорожі країнами Європи, мусульманським світом, Україною, застосовується візуальний алгоритм «занурення» в мистецтво, прийом зіставлення «минуле-сучасність» у межах країни тощо.

Міхно Олександр Петрович, доктор педагогічних наук, директор Педагогічного музею, представив онлайн-проєкти Педагогічного музею України, з-поміж яких - електронний інформаційний ресурс «Музейна педагогіка», «Педагогічний календар», «Цитата від музи педагогіки», «Сухомлинський серед зірок», «Сковорода300», «Топ 5 за версією Педагогічного музею України», «Педагогічна мапа Києва» та ін.

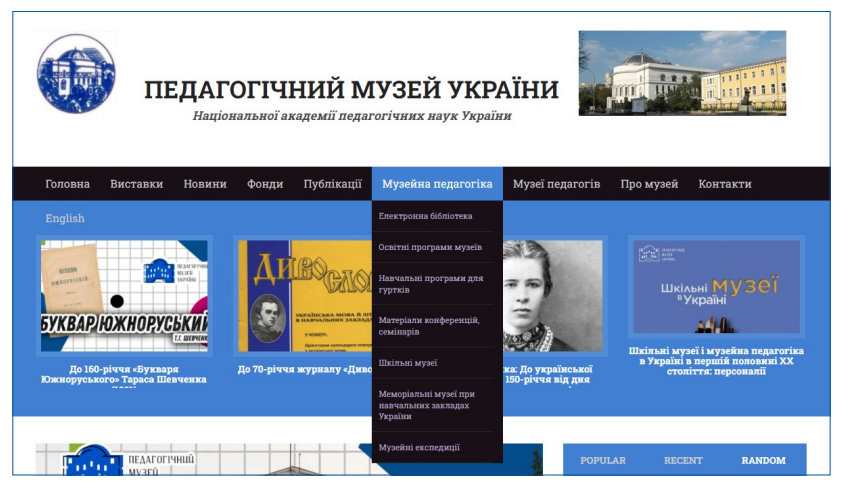

Доктор педагогічних наук, професор, професор кафедри теорії та методики музичної освіти, хорового співу і диригування факультету мистецтв імені Анатолія Авдієвського Національного педагогічного університету імені М.П. Драгоманова Сергій Семенович Горбенко відзначив професійні й особистісні якості Оксани Петрівни Рудницької, з якою працював поруч на факультеті мистецтв, окреслив інноваційні для поступу мистецької освіти ідеї дослідниці щодо гуманізації навчання, використання особистісно орієнтованого підходу до розвитку творчої особистості, формування педагогічного мислення майбутнього вчителя, утвердження пріоритету прекрасного у педагогічній освіті тощо.

Виступи відомих науковців, педагогівпрактиків визначили проблеми й перспективи удосконалення теорії і практики мистецької, педагогічної освіти, уможливили окреслення досягнень сучасної педагогічної теорії й освітньої практики у використанні потенціалу мистецької педагогіки тощо. Доповіді досвідчених дослідників висвітлили вагомі проблеми сучасної неперервної освіти: теоретичні та практичні аспекти оцінювання навчальних досягнень учнів (Міхаль Гнатюк, доктор філософії, науковий співробітник та викладач Інституту права, психології та інноваційної освіти Національного університету «Львівська політехніка»); значення основного навчального плану в роботі вчителя початкової школи в системі освіти (Тереза Яніцка-Панек, професор Державного закладу вищої освіти імені Стефана Баторія у Скерневіцах (м. Скерневиці, Республіка Польща); сертифікатна програма «Організація та режисура культурно-мистецьких проєктів» в освітньому процесі Херсонського державного університету (Лідія Іванівна Лимаренко, доктор педагогічних наук, професор кафедри культурології, завідувач кафедри культурології Херсонського державного університету, заслужена працівниця культури України); формування дослідницьких умінь як крок до самореалізації в умовах неформальної освіти (Ольга Миколаївна Ходацькa, аспірантка Інституту педагогічної освіти і освіти дорослих імені Івана Зязюна НАПН України, вчитель української мови і літератури гімназіїінтернату № 13 м. Києва).

Під час секційних засідань здобутки теорії і практики педагогічної, мистецької освіти були представлені науковцями, педагогами, викладачами, студентами закладів освіти з різних регіонів України: Національного педагогічного університету імені М.П. Драгоманова, Уманського державного педагогічного університету імені Павла Тичини, Полтавського національного педагогічного університету імені В.Г. Короленка, Херсонського державного університету, Чернівецького національного університету імені Юрія Федьковича, Сумського державного педагогічного університету імені А.С. Макаренка, Бердянського державного педагогічного університету та ін. Проблематика секцій охоплювала спектр актуальних проблем: філософсько-аксіологічні та андрагогічні засади педагогічної освіти; педагогічна освіта в Україні: тенденції і перспективи реформування; мистецька освіта у вимірах сучасних модернізаційних змін; зарубіжний досвід підготовки вчителя: теорія і практика; педагогічна майстерність як система професійномистецьких компетентностей; музейна педагогіка - проблеми, сьогодення, перспективи.

Завідувач наукової бібліотеки Інституту педагогічної освіти і освіти дорослих імені Івана Зязюна НАПН України Людмила Наумівна Штома представила виставку наукових праць професора Оксани Петрівни Рудницької та нових науково- 
педагогічних і мистецьких видань за 20202021 рр, з якими частково можна ознайомитися в електронній бібліотеці Інституту педагогічної освіти і освіти дорослих імені Івана Зязюна НАПН України.

Поетичним акордом заходу прозвучав вірш на честь вшанування пам'яті Оксани Петрівни Рудницької за авторством доктора педагогічних наук, професора Григорія Петровича Васяновича:

«А Ти усім, мов музика із ранку,

А Ти, як спів сумний моїй душі,

Тобі чуття пречисті - до останку,

І сріблом виткані ці болісні вірші.

В житті Ти брала щонайвищу ноту,

Ти брала щонайвищу висоту,

Наповнювала, наче бджілка соти,

Злеліяно-омріяну мету...»

За результатами проведення читань буде підготовлено випуск збірника матеріалів. 3 попередніми випусками можна ознайомитися в електронній бібліотеці Інституту.

у підсумку учасники акцентували увагу на необхідності підготовки повного видання наукових і навчально-методичних праць Оксани Петрівни
Рудницької, що стане вагомим методологічним підґрунтям для оновлення змісту, методів, форм і технологій навчання у сфері мистецької і педагогічної освіти.

\section{СПИСОК ВИКОРИСТАНИХ ДЖЕРЕЛ}

Вовк, М.П. (2021, 1 грудня). Неперервна педагогічна освіта XXI століття: досвід, інновації, тенденції. Інститут педагогічної освіти і освіти дорослих імені Івана Зязюна НАПН України. https://bit.ly/3E9Lk8v

Вовк, М.П., Грищенко, Ю.В., Соломаха, С.О., Філіпчук, Н.О., \& Ходаківська, С.В. (уклад.). (2021). Педагогічна освіта в Україні: теорія і практика : словник. Київ: Інститут педагогічної освіти і освіти дорослих імені Івана Зязюна НАПН України. https:// lib.iitta.gov.ua/728146/

Рудницька О.П. (2002). Педагогіка: загальна та мистецька: навчальний посібник. Київ: Інтерпроф.

Сотська, Г.І., \& Вовк, М.П. (наук. ред.). (2020). Hеперервна педагогічна освіта XXI столітmя : збірник матеріалів XVII Міжнародних педагогічно-мистецьких читань пам'яті проф. О.П. Рудницької, 3(15). Київ: Талком. https://bit.ly/3HqqqEJ

Сотська, Г.І., \& Вовк, М.П. (наук. ред.). (2021). Неперервна педагогічна освіта XXI столітmя : збірник матеріалів XVIII Міжнародних педагогічно-мистецьких читань пам'яті проф. О.П. Рудницької, 4(16). Київ: Талком. https://bit.ly/3Hq2m4F

\section{CONTINUOUS TEACHER EDUCATION OF THE 21st CENTURY: EXPERIENCE, INNOVATIONS, TRENDS 19th International Art and Pedagogical Readings in Memory of Professor Oksana Rudnytska}

\section{Myroslava Vovk}

DSc in Pedagogy, Senior Researcher, Head of the Department for Content and Technologies of Teacher Education, Ivan Ziaziun Institute of Pedagogical and Adult Education of the National Academy of Educational Sciences of Ukraine, Kyiv, Ukraine Nataliia Filipchuk

DSc in Pedagogy, Senior Researcher, Leading Research Fellow of the Department for Content and Technologies of Teacher Education, Ivan Ziaziun Institute of Pedagogical and Adult Education of the National Academy of Educational Sciences of Ukraine, Kyiv, Ukraine Svitlana Solomakha

PhD in Pedagogy, Senior Research Fellow of the Department for Content and

Technologies of Teacher Education, Ivan Ziaziun Institute of Pedagogical and Adult

Education of the National Academy of Educational Sciences of Ukraine, Kyiv, Ukraine

Abstract. The paper enlightens the problems of the 21st International Art and Pedagogical Readings in Memory of Professor Oksana Rudnytska "Continuous Teacher Education in Ukraine and Abroad: Experience, Innovations, Trends" (December 1, 2021, Kyiv), the organisation of which is aimed at establishing partnerships between education and research institutions in reforming art and pedagogical education, honouring the memory of significant figures for Ukrainian education, great personalities in the production of innovative research ideas. Emphasis is placed on the scientific heritage of Oksana Rudnytska (1946-2002), DSc in Pedagogy, Professor, who became one of the founders of art education in Ukraine; she substantiated the methodological, theoretical foundations of art pedagogy. The achievements of the Department for Content and Technologies of Teacher Education of Ivan Ziaziun Institute of Pedagogical and Adult Education of the National Academy of Educational Sciences of Ukraine in preserving the scientific heritage of Oksana Rudnytska and the prospects of researcher's ideas popularisation in the modern scientific and educational space are outlined.

Keywords: teacher education; art education; Oksana Rudnytska; art and pedagogical readings; scientific heritage; Ivan Ziaziun Institute of Pedagogical and Adult Education of NAES of Ukraine. 